\title{
Pemanfaatan Pleiades untuk Penyusunan Sistem Informasi Penggunaan Tanah Berbasis Bidang
}

\author{
Feris Adisca Nugraha, Westi Utami \\ Masuk: 18012021 / Diterima: 09102021 / Dipublikasi: 01122021
}

\begin{abstract}
Land as a crucial asset requires transparent, sustainable, and integrated management. An information system is needed to provide convenience in managing the land database. This study aims to develop a field-based land use information system as an essential element in the management system for planning, design, and decision making. The research method is carried out spatially to map land parcels and land use, while research and development build a plot-based land use information system. Data on land parcels were obtained through Geo-KKP and PBB parcel data, while land use data were obtained through interpretation of Pleiades imagery. The results showed that the Pleiades imagery provided convenience in presenting a complete map of land parcels as a base map/control in compiling a map of land parcels and providing detailed land use information. The study results also show that the information system built can facilitate the presentation of field-based land use data and other information related to land objects and subjects. This information system can formulate parcel-based policies such as the preparation of field-based Land Value Zones, the preparation of Detailed Spatial Plans, and the preparation of sustainable agricultural land.
\end{abstract}

Key words: Land Information System; Land Use; Field Map; Pleiades

\begin{abstract}
Abstrak Tanah sebagai aset krusial memerlukan pengelolaan yang transparan, berkelanjutan, dan terintegrasi. Untuk mendukung pengelolaan tersebut dibutuhkan sistem informasi agar memberikan kemudahan dalam mengelola basis data pertanahan. Penelitian ini bertujuan menyusun sistem informasi penggunaan tanah berbasis bidang sebagai salah satu unsur penting dalam tata pengelolaan guna perencanaan, perancangan dan pengambilan keputusan. Metode penelitian dilakukan secara spasial untuk memetakan bidang tanah dan penggunaan tanah, sementara research and development digunakan untuk membangun Sistem Informasi penggunaan tanah berbasis bidang. Data bidang tanah diperoleh melalui Geo-KKP dan data persil PBB, sementara data penggunaan tanah diperoleh melalui interpretasi citra Pleiades. Hasil penelitian menunjukkan citra Pleiades mampu memberikan kemudahan dalam menyajikan peta bidang tanah secara lengkap, menjadi basemap/kontrol dalam menyusun peta bidang tanah dan menyediakan informasi penggunaan tanah secara detail. Hasil kajian juga menunjukkan sistem informasi yang dibangun mampu mempermudah penyajian data penggunaan tanah berbasis bidang serta informasi lain terkait obyek dan subyek tanah. Sistem informasi ini dapat dimanfaatakan sebagai dasar dalam menyusun kebijakan berbasis persil seperti penyusunan Zona Nilai Tanah berbasis bidang, penyusunan Rencana Detail Tata Ruang maupun penyusunan Lahan Pertanian Berkelanjutan (LP2B).
\end{abstract}

Kata kunci: Sistem Informasi Pertanahan; Penggunaan Tanah; Peta Bidang; Pleiades

This is an open access article under the CC BY-SA license.

Copyright $(2021$ by Author. Published by Universitas Pendidikan Ganesha.

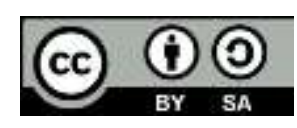

${ }^{1}$ Feris Adisca Nugraha, ${ }^{1}$ Westi Utami

${ }^{1}$ Sekolah Tinggi Pertanahan Nasional, Indonesia

westiutami@stpn.ac.id

\section{Pendahuluan}

Tekanan penduduk yang terus meningkat serta pembangunan yang tidak sebanding dengan ketersediaan tanah seringkali mengakibatkan ketidaksesuaian penggunaan dan 
pemanfaatan tanah, pelanggaran tata ruang hingga degradasi lingkungan (Khadiyanto 2005; Puspitasari 2015; Wulansari 2017; Hastuti 2020; Utami et al 2021). Upaya pengaturan dan optimalisasi pemanfaatan tanah yang diwujudkan dalam Rencana Tata Ruang Wilayah (RTRW) belum cukup efektif untuk mengatur pemanfaatan tanah secara rinci (Jazuli 2017). Untuk itu penyusunan Rencana Detail Tata Ruang (RDTR) yang di dalamnya memuat pengaturan zonasi diharapkan mampu memberikan arahan penggunaan dan pemanfaatan tanah hingga level lebih detail (Korlena et al., 2011) yakni tingkat desa bahkan hingga bidang per bidang. Namun kondisi yang terjadi, ketersediaan data penggunaan tanah berbasis bidang dimana di dalamnya memuat data pemilikan, penguasaan, penggunaan tanah kondisinya masih terbatas. Hal inilah yang menjadikan beberapa Kabupaten/Kota di Indonesia belum mampu menyusun RDTR (Nurwadjedi dkk 2019). Sementara dengan belum adanya RDTR berkorelasi terhadap sulitnya menertibkan tata ruang bahkan hingga menghambat penerapan Online Single Submission (OSS) dalam rangka Penerbitan Izin Lokasi bagi investor untuk menanamkan usaha pada suatu wilayah (Santoso et.al 2020).

Perkembangan teknologi penginderaan jauh diantaranya dengan diluncurkannya citra Pleiades mampu memberikan kemudahan dalam memperoleh data tutupan lahan/penggunaan lahan. Resolusi spasial citra Pleiades pada citra pankromatik mencapai kedetailan 0,5 m dan pada multispectral $2 \mathrm{~m}$ menjadikan informasi tutupan lahan dapat diinterpretasi secara lebih detail dan akurat (Hapsari et.al 2015). Citra ini tentunya dapat digunakan sebagai supporting data guna menyusun berbagai pekerjaan pemetaan skala besar (Gifari 2019). Dari berbagai kajian menunjukkan bahwasanya kualitas data yang dihasilkan dari citra ini sangat tinggi sehingga dapat digunakan untuk analisis pada kajian penggunaan tanah hingga bidang per bidang. Optimalisasi pemanfaatan citra ini harus terus dilakukan agar kebutuhan basis data dapat tersedia untuk menyelesaikan berbagai kepentingan (Pujianto et.al 2016).

Memasuki era revolusi industri 4.0, ketersediaan basis data pemilikan, penguasaan, penggunaan maupun pemanfaatan tanah yang diwujudkan dalam Sistem Informasi Pertanahan/SIP menjadi sesuatu yang sangat diperlukan mengingat tantangan pengelolaan tanah ke depan membutuhkan data yang sifatnya akuntable, akurat, terintegrasi dan memiliki kekuatan hukum secara pasti (Asyita \& Taufik 2013). Geo-KKP sebagai sistem terintegrasi memuat informasi bidang-bidang tanah secara spasial dan memuat data pemilikan/penguasaan tanah diharapkan mampu menyediakan basis data semua bidang tanah secara lengkap (Ginanjar et.al 2014). Namun kondisi yang ada saat ini, terhadap beberapa lokasi, data tersebut belum semuanya terpetakan secara lengkap (Kusuma \& Utami 2020). Selain permasalahan keterbatasan data, penyusunan serta penyajian basis data spasial perlu dilakukan secara sistematis, terintegrasi dan informatif sehingga mampu memberikan kemudahan bagi pengguna untuk 
mengakses informasi guna menyusun kebijakan yang tepat. Inovasi pelayanan pertanahan digital guna mewujudkan pelayanan publik yang mudah diakses, agar mampu meningkatkan produktivitas kinerja dan mampu melayani masyarakat secara efektif, efisien tentunya perlu ditingkatkan agar mewujudkan percepatan Reformasi Birokrasi dan Pencapaian Pembangunan Berkelanjutan. Mendasarkan dari problematika sebagaimana tersebut di atas, kajian ini bertujuan untuk menyusun Sistem Informasi Pertanahan bidang tanah secara lengkap berisi data pemilikan, penguasaan maupun penggunaan tanah dengan mengoptimalkan pemanfaatan citra Pleiades.

\section{Metode}

Penelitian ini dilakukan dengan pendekatan spasial untuk memetakan data penggunaan tanah dan data pemilikan/penguasaan bidang tanah, sementara pendekatan research and development digunakan untuk menyusun Sistem Informasi penggunaan tanah. Penelitian dilaksanakan di Desa Blimbing, Kecamatan Gatak, Kabupaten Sukoharjo, Jawa Tengah, dimana secara geografis lokasi ini berada pada Kawasan sub-urban yang rawan terjadi alih fungsi lahan. Data penelitian berupa data Geo KKP yang menyimpan data bidang tanah yang sudah terdaftar, data Peta Pajak Bumi dan Bangunan/ PBB, citra satelit Pleiades Tahun 2018, dan data hasil wawancara dengan responden.

Perolehan data spasial dilakukan melalui interpretasi citra satelit Pleiades dengan mendasarkan pada sembilan kunci interpretasi, sementara pengumpulan data tekstual dilakukan melalui wawancara dengan Pegawai di Kantor Pertanahan BPN Kabupaten Sukoharjo dan studi dokumen. Dalam kajian ini dilakukan pengujian sistem informasi untuk mengetahui apakah sistem informasi dapat berjalan sesuai standar. Pemilihan responden untuk pengujian sampel dilakukan melalui purposive sampling kepada instansi yang menggunakan sistem informasi yang dibangun.

Responden selaku penguji sistem meliputi 4 (empat) orang yakni dari 2 (dua) orang merupakan PNS Kantor Pertanahan Kabupaten Sukoharjo dan 2 (dua) orang PNS Dinas Pekerjaaan Umum dan Penataan Ruang Kabupaten Sukoharjo Selain melakukan pengujian sistem dalam kajian ini juga dilakukan survei lapang untuk memastikan akurasi batas bidang tanah dan akurasi hasil interpretasi penggunan tanah. Diagram alir penelitian disajikan dalam Gambar 1 , sementara tahapan dalam penyusunan sistem informasi disajikan pada Gambar 2 yang terdiri desain basis data penggunaan tanah dan desain layout, programming dan pengujian. Sistem informasi yang dibangun dalam kajian ini berbeda dengan sistem informasi pada Geo-KKP, dimana dalam sistem informasi yang dibangun data yang tersaji sudah mencakup semua bidang tanah dalam satu desa dan sudah terdapat penambahan atribut berisi data penggunaan tanah. Diagram alir penelitian dalam penelitian ini dapat dilihat pada Gambar 1. 
Pemanfaatan Pleiades untuk Penyusunan Sistem Informasi Penggunaan Tanah Berbasis Bidang/Feris Adisca Nugraha, Westi Utami

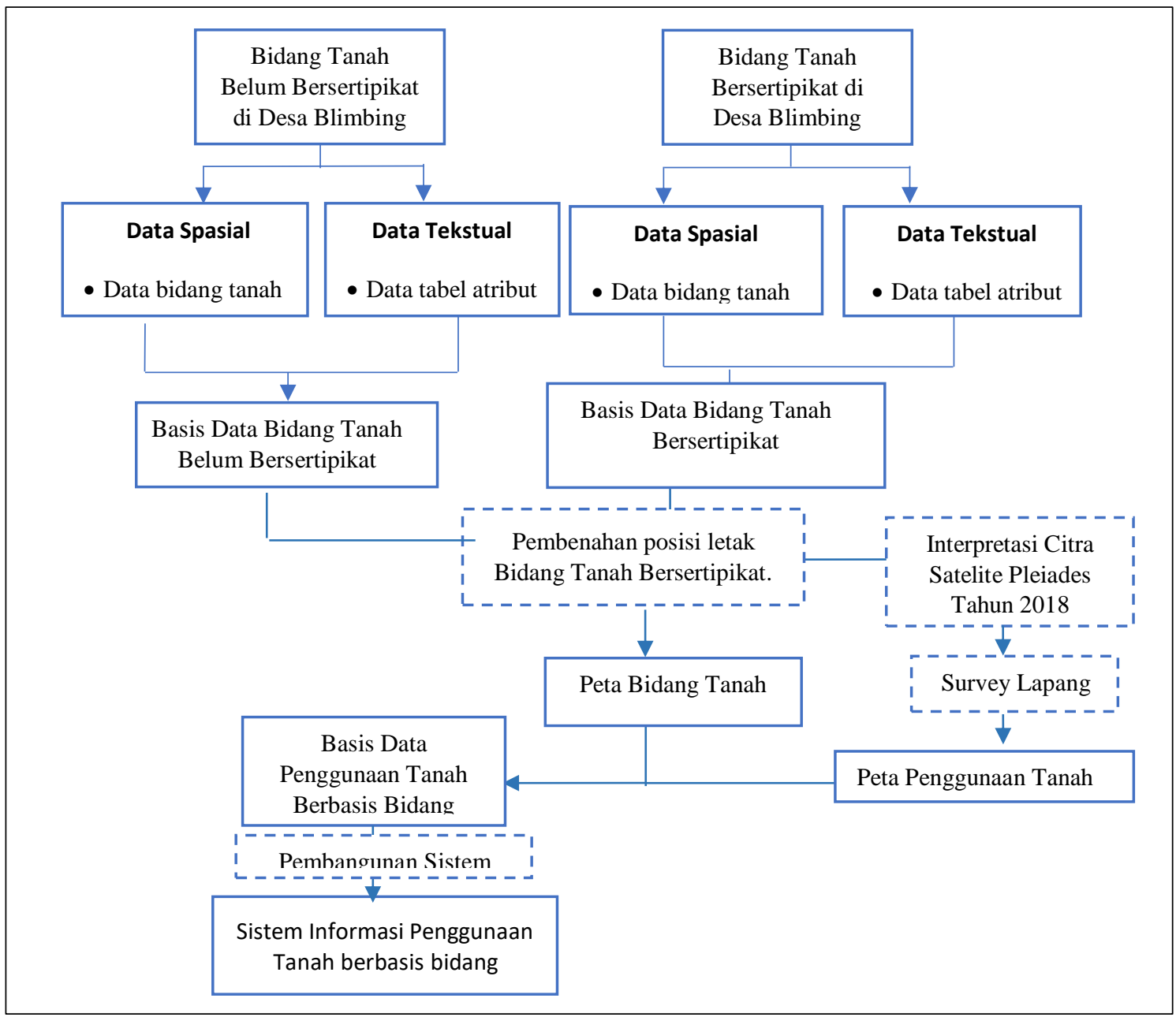

Gambar 1. Diagram Alir Penelitian

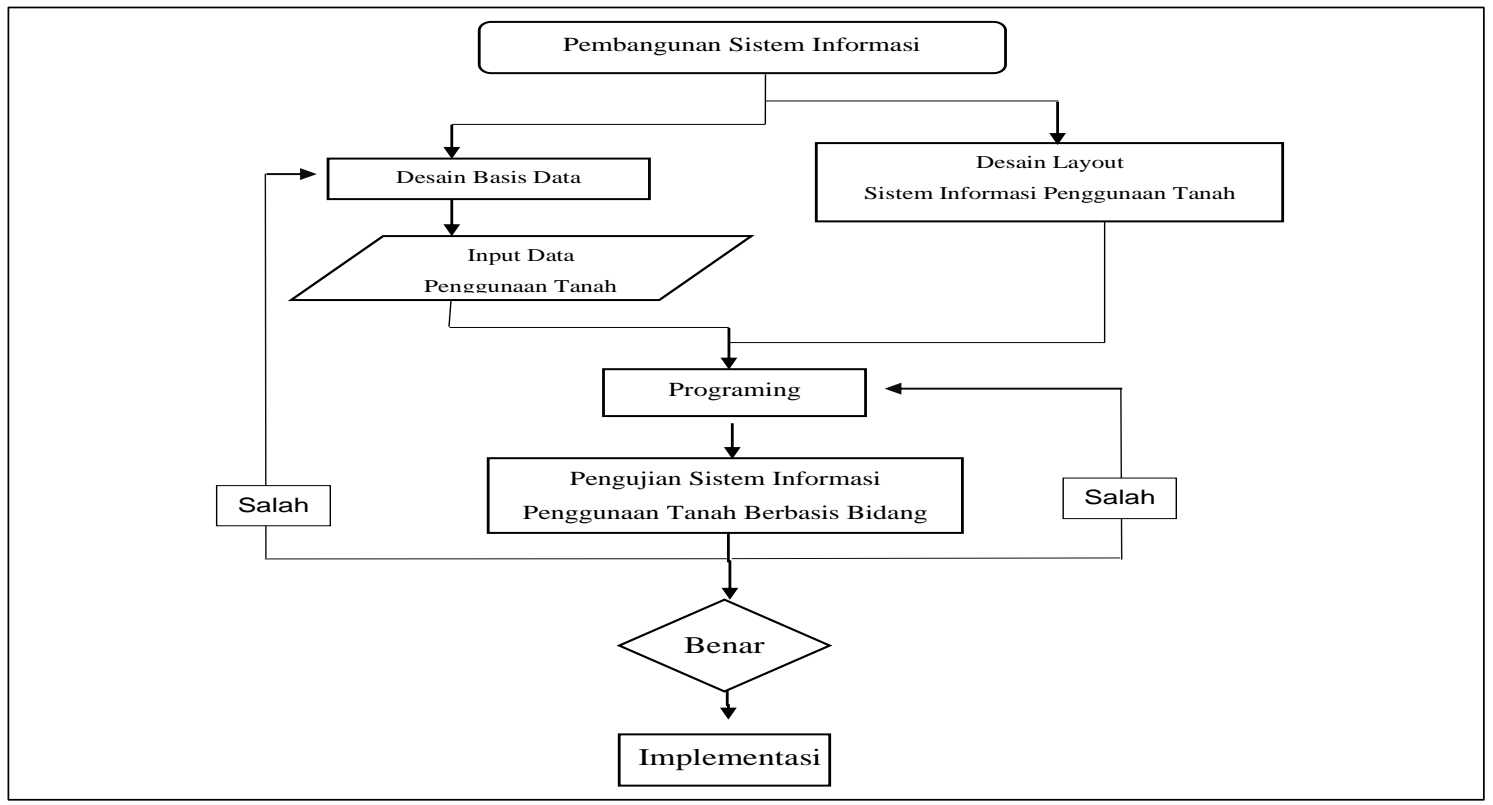

Gambar 2. Diagram Alir Pembangunan Sistem Informasi Pertanahan 


\section{Hasil dan Pembahasan Pembangunan Sistem Informasi Penggunaan Tanah Berbasis Bidang}

$\begin{array}{ccr}\text { Penyusunan Basis } & \text { Data Bidang Tanah } \\ \text { Data } & \text { spasial } & \text { dalam } \\ \text { pembangunan } & \text { sistem } & \text { informasi }\end{array}$ penggunaan tanah berbasis bidang meliputi data bidang tanah dan data penggunaan tanah. Penyusunan data bidang tanah dilakukan dengan memanfaatkan data spasial GeoKKP Web yang diperoleh dari Kantor Pertanahan Kabupaten Sukoharjo. Di dalam data Geo KKP Web tersebut memuat informasi meliputi Nomor Identifikasi Bidang (NIB), Nomor Hak, Nomor Surat Ukur dan nama pemilik/pemegang hak atas tanah. Dari hasil pengamatan menunjukkan bahwasanya di Desa Blimbing, kondisi data Geo KKP masih banyak yang belum terpetakan sebagaimana dapat dilihat pada Gambar 3. Belum terpetakannya bidang tanah tersebut dapat disebabkan oleh beberapa kemungkinan diantaranya tanah belum disertipikatkan, atau dapat pula tanah sudah bersertipikat namun belum terpetakan dalam aplikasi. Hal inilah yang mengakibatkan belum terwujudnya Desa lengkap/ basis data bidang tanah secara menyeluruh. Selain belum lengkapnya, dari hasil overlay dengan peta batas administrasi dan overlay dengan kondisi eksisting melalui peta citra pleiades menunjukkan beberapa bidang tanah dalam Geo KKP terdapat yang missplace. Kondisi data yang belum akurat dan terdapat ketidaksesuaian dengan kondisi eksisting ini tentunya belum dapat digunakan sebagai basis data dalam penelitian.

Untuk menyelesaikan permasalahan ini maka upaya yang dilakukan yakni melalui perbaikan data dengan melakukan tumpang susun antara data GeoKKP dengan citra Pleiades yang sudah dilakukan georeference. Citra Pleiades ini sangat membantu di dalam melakukan perbaikan data bidang tanah terutama yang berada pada area persawahan. Kemampuan resolusi spasial Pleiades yang cukup tinggi yakni mencapai $0,5 \mathrm{~m}$ mampu memberikan kenampakan batas fisik antara bidang sawah satu dengan lainnya (pembatas tersebut jika di Jawa disebut dengan galengan/jalan kecil setapak) yang nampak jelas untuk dilakukan interpretasi. Pembenahan data bidang tanah yang misplace dapat dilakukan secara lebih cepat, lebih mudah dan lebih tepat dengan menempatkan citra Pleiades sebagai basemap.

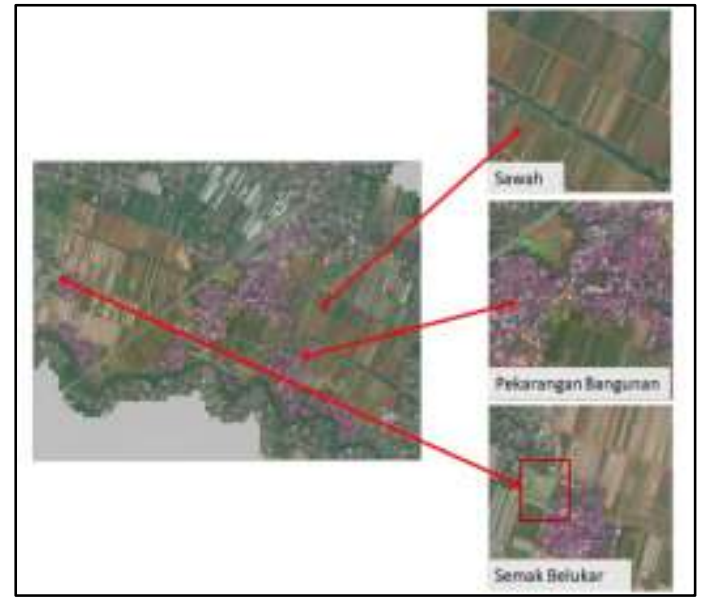

Gambar 3. Pemanfaatan Citra Pleiades sebagai Base Map dalam Interpretasi serta Kontrol Batas Bidang Tanah 
Hasil pembenahan data Geo KKP yang dilakukan secara on screen mendasarkan citra Pleiades selanjutnya diperlukan kontrol kualitas data. Upaya ini dilakukan melalui survei lapang terutama terhadap beberapa bidang tanah yang kurang nampak jelas pada citra (pemukiman, kebun). Sementara terhadap bidang tanah sawah maka sampling lokasi hanya terbatas karena sudah cukup jelas diperoleh dari pleiades. Berdasarkan hasil analisis dari Citra Pleiades dan hasil survei lapang maka data Geo KKP yang sudah dilakukan perbaikan selanjutnya dapat digunakan sebagai basis data bidang tanah. Sebaran data bidang tanah yang terpetakan dalam aplikasi Geo-KKP disajikan sebagaimana Gambar 4 berikut.

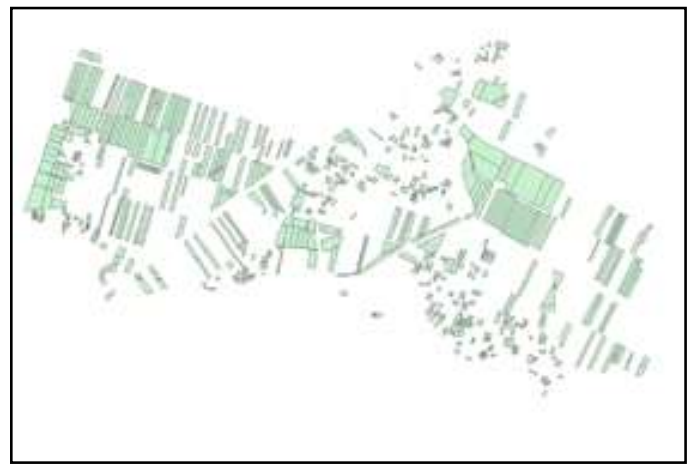

Gambar 4. SHP data spasial bidang tanah GeoKKP Web

Berdasarkan Gambar 4 menunjukkan bahwasanya masih terdapat beberapa bidang tanah yang belum terpetakan. Sebagai upaya melengkapi bidang tanah yang masih kosong dalam penelitian ini digunakan peta blok PBB Desa Blimbing sebagaimana tersaji pada Gambar 5.

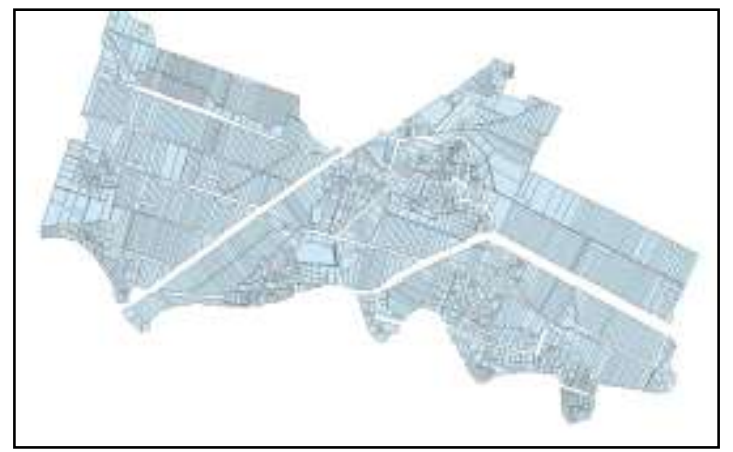

Gambar 5. SHP hasil digitasi Peta Blok PBB Desa Blimbing

Dari gambar 5, di dalam peta PBB jumlah dan batas bidang tanah di dalam satu desa tersaji secara utuh dan lengkap. Akan tetapi akurasi dari data PBB ini memiliki kualitas lebih rendah apabila dibandingkan dengan hasil pemetaan yang dilakukan secara kadastral oleh BPN. Dalam hal ini maka data peta PBB dijadikan sebagai basis data tambahan untuk melengkapi bidang tanah yang belum ada dalam Geo-KKP. Untuk menyajikan data bidang tanah secara lengkap, maka terhadap data Geo KKP dengan data peta PBB dilakukan overlay sebagaimana tersaji pada Gambar 6 . Bidang tanah dengan warna merah merupakan hasil overlay yang diperoleh dari peta $\mathrm{PBB}$, sementara warna biru muda merupakan sebaran bidang tanah dari hasil peta Geo KKP. Di dalam proses overlay antara peta GeoKKP dengan peta PBB ini digunakan basemap citra pleiades dengan komposit RGB (Red-Green-Blue). Basemap ini berfungsi untuk memudahkan kenampakan asli obyekobyek yang ada di lapangan dan dijadikan sebagai data kontrol serta acuan terhadap penyusunan basis data bidang secara lengkap. 


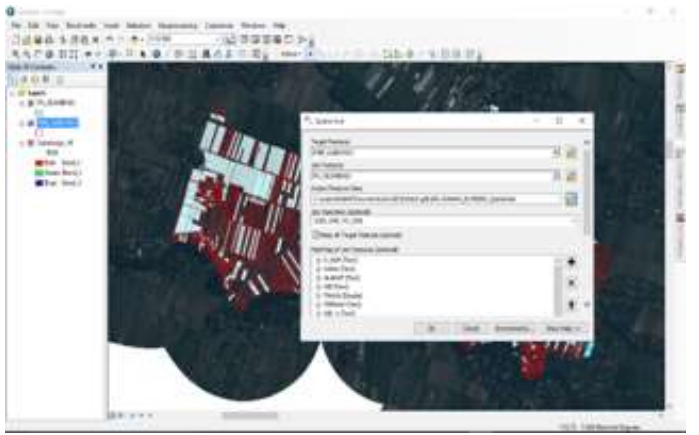

Gambar 6. Proses overlay SHP bidang tanah GeoKKP dengan bidang tanah PBB

Mekanisme penggabungan data bidang tanah dari data Geo-KKP dan peta PBB merupakan salah satu cara untuk memperoleh basis data bidang tanah secara lengkap. Namun apabila program PTSL sudah mampu memetakan semua bidang tanah dalam sebuah desa, maka penyusunan basis data bidang tanah cukup diperoleh melalui data tersebut. Mengingat urgensi kebutuhan data bidang tanah cukup mendesak, maka Kementerian ATR/BPN terus berupaya agar program strategi PTSL ini dapat mewujudkan basis data desa lengkap sebagai basis data penyediaan peta skala besar berbasis bidang tanah. Terwujudnya bidang tanah secara lengkap melalui aplikasi GeoKKP ini harapanya mampu meningkatkan kinerja kementerian ATR/BPN, mengurangi konflik/sengketa pertanahan maupun mampu menyediakan basis data guna medorong terwujudnya one map policy (Silviana 2019).

Penyusunan Basis Data Penggunaan Tanah Berbasis Bidang

Data penggunaan tanah dalam kajian ini diperoleh dari hasil interpretasi citra satelit pleiades tahun 2018. Untuk memperoleh informasi tutupan lahan secara detail interpretasi data dilakukan melalui pendekatan 9 kunci interpretasi (rona/warna, tekstur, pola, bentuk, ukuran, asosiasi, tinggi, bayangan, situs). Pemilihan metode interpertasi secara visual ini dimaksudkan agar hasil klasifikasi obyek penggunaan tanah dapat disajikan secara lebih detail dan hasil yang disajikan lebih akurat. Sebagaimana kajian yang dilakukan oleh Manalu et.al (2016), pemilihan metode klasifikasi secera visual memiliki tingkat akurasi dan kelengkapan lebih baik dbandingkan dengan metode klasifikasi digital.

Dalam kajian ini penggunaan lahan diklasifikasikan menjadi: penggunaan aneka industri, gedung olahraga, jasa instansi pemerintah, jasa kesehatan, jasa keuangan, jasa pendidikan, jasa perdagangan, sarana peribadatan, jasa sewa, jasa telekomunikasi, kampung padat tidak teratur, kebun campuran, kuburan/pemakaman, lapangan olahraga perumahan jarang, sawah irigasi lebih dari $2 x$ padi/tahun, tanah kosong sudah diperuntukan. Hasil interpretasi penggunaan lahan citra pleiades dalam kajian ini disajikan pada Gambar 7.

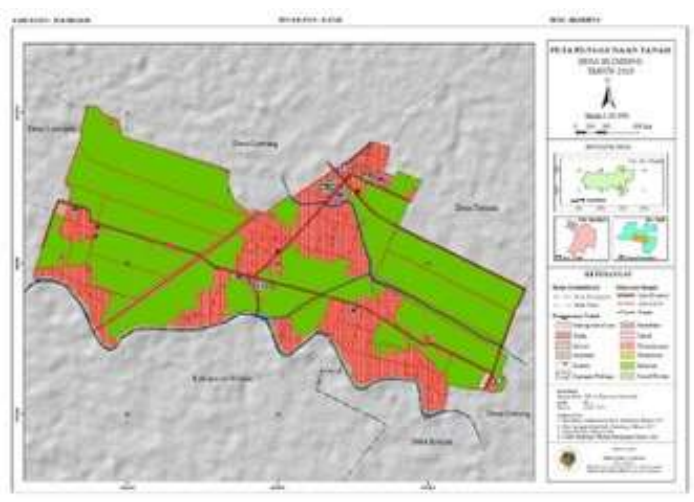

Gambar 7. Peta Penggunaan Lahan Berdasarkan Interpretasi Citra Pleiades 
Dari hasil analisis yang dilakukan terhadap citra Pleiades dengan resolusi spasial hingga mencapai $0,5 \mathrm{~m}$ memberikan kemudahan dalam mengenali obyek-obyek di permukaan bumi. Citra ini mampu memberikan perbedaaan secara signifikan terhadap obyek lahan terbangun antara perkampungan dengan fasilitas pendidikan, salah satunya dibedakan dengan ukuran bangunan pada fasilitas pendidikan yang lebih besar dan di dalamnya seringkali terdapat fasilitas lapangan upacara/adanya tembok pembatas. Sebagai upaya menjaga kualitas data yang disajikan dan untuk memastikan obyek yang diklasifikasikan memiliki keakuratan tinggi, di dalam kajian ini dilakukan ground check/survei lapang untuk mengecek hasil interpretasi dengan obyek yang ada di lapangan.

\section{Penyusunan basis data penggunaan tanah berbasis bidang}

Basis data penggunaan tanah
untuk penyusunan informasi
penggunaan tanah ini dilakukan dengan
melakukan overlay semua data bidang
tanah (bersertipikat maupun belum
bersertipikat) dengan data penggunaan
tanah aktual. Hasil overlay kedua peta
ini selanjutnya diperoleh data bidang
tanah dan data penggunaan tanah
dalam satu basis data. Hasil distribusi
spasial penggunaan tanah berbasis
bidang disajikan pada Gambar 8 .

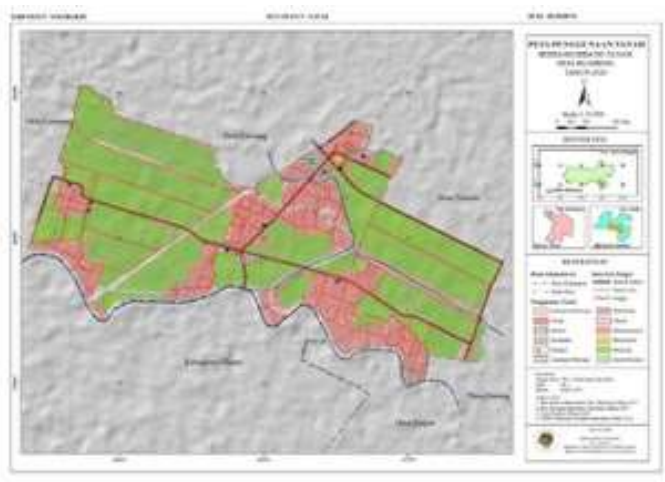

Gambar 8. Peta Penggunaan Tanah Berbasis Bidang

Penyusunan peta penggunaan tanah berbasis bidang ini mampu memberikan kemudahan bagi user untuk mengetahui sebaran penggunaan tanah dengan informasi penguasaan/pemilikannya. Lebih lanjut pemanfaatan data sebaran penggunaan tanah berbasis bidang juga dapat digunakan untuk mengidentifikasi pola penguasaan tanah apakah merata atau mengumpul pada kelompok masyarakat tertentu atau dikuasai oleh badan hukum tertentu.

Pemanfaatan lain dari adanya basis data ini juga dapat digunakan untuk mengetahui tingkat kepemilikan rata-rata lahan pertanian oleh para petani. Melalui sistem informasi ini juga dapat diidentifikasi apakah dalam wilayah tersebut terdapat adanya tanah absentee. Dari hasil analisis yang dilakukan di Desa Blimbing terdapat 2.238 bidang tanah, dimana distribusi penggunaan tanahnya disajikan pada Tabel 1. 
Tabel 1. Penggunaan Tanah Berbasis Bidang di Desa Blimbing

\begin{tabular}{|c|c|c|}
\hline No & $\begin{array}{c}\text { Jenis Penggunaan } \\
\text { Tanah } \\
\end{array}$ & $\begin{array}{c}\text { Jml Bidang } \\
\text { Tanah }\end{array}$ \\
\hline 1 & Aneka Industri & 5 \\
\hline 2 & Gedung Olahraga & 2 \\
\hline 3 & $\begin{array}{l}\text { Jasa Instansi } \\
\text { Pemerintah }\end{array}$ & 5 \\
\hline 4 & Jasa Kesehatan & 2 \\
\hline 5 & Jasa Keuangan & 2 \\
\hline 6 & Jasa Pendidikan & 14 \\
\hline 7 & Jasa Perdagangan & 84 \\
\hline 8 & Jasa Peribadatan & 10 \\
\hline 9 & Jasa Sewa & 3 \\
\hline 10 & Jasa Telekomunikasi & 1 \\
\hline 11 & $\begin{array}{l}\text { Kampung Padat Tidak } \\
\text { Teratur }\end{array}$ & 1142 \\
\hline 12 & Kebun Campuran & 13 \\
\hline 13 & Kuburan/Pemakaman & 16 \\
\hline 14 & Lapangan Olahraga & 2 \\
\hline 15 & Perumahan Jarang & 9 \\
\hline 16 & $\begin{array}{l}\text { Sawah Irigasi Lebih } \\
\text { dari 2x Padi/Tahun }\end{array}$ & 917 \\
\hline 17 & $\begin{array}{l}\text { Tanah Kosong Sudah } \\
\text { Diperuntukan }\end{array}$ & 11 \\
\hline & Jumlah & 2238 \\
\hline
\end{tabular}

Data di atas menunjukkan bahwasanya sebagian besar bidang tanah di Desa Blimbing berupa pemukiman padat tidak teratur tumbuh secara alami yang mencirikan kondisi pedesaan. Penggunaan lahan berupa bidang sawah mendominasi secara luasan dengan jumlah bidang hingga 917 bidang. Hal ini mengindikasikan sebagian besar masyarakat di desa Blimbing masih mengandalkan lahan pertanian sebagai sumber penghidupan masyarakat. Keberadaan sawah beririgasi dengan 2 x panen di lokasi ini sekiranya perlu mendapatkan perlindungan mengingat secara infrastruktur ketersediaan saluran irigasi sudah memadai dan kemampuan lahannya cukup bagus sehingga mampu menghasilkan panen hingga 2x/tahun. Sebagai desa yang berada pada kawasan pinggiran pada wilayah ini sudah terdapat 5 bangunan industri yang menandakan bahwasanya wilayah ini memiliki lokasi strategis sebagai kawasan pengembangan industri. Tentu saja masuknya industri pada kawasan pedesaan i dapat memicu laju perubahan penggunaan lahan pertanian menjadi non pertanian.

Pembuatan GeoJson

GeoJson merupakan format standar terbuka yang dirancang untuk mewakili fitur geografis sederhana (Arief 2020). Pembuatan layer bidang ini bertujuan untuk mengetahui kebenaran mengenai batas dan bentuk bidang tanah serta dapat digunakan dalam rangka pengecekan apabila telah terjadi perubahan terhadap bidang tanah induk. Penggunaan layer bidang juga berfungsi sebagai koreksi terhadap bidang tanah yang belum terpetakan ataupun telah terjadi pemecahan ataupun pemisahan bidang tanah. Pembuatan GeoJson dalam kajian ini dilakukan dengan software Global Mapper menggunakan fungsi Export $\rightarrow$ Export Vector/Lidar Format $\rightarrow$ GeoJson (JavaScript Object Notation). Adapun gambar proses pembuatan GeoJson disajikan sebagaimana Gambar 9.

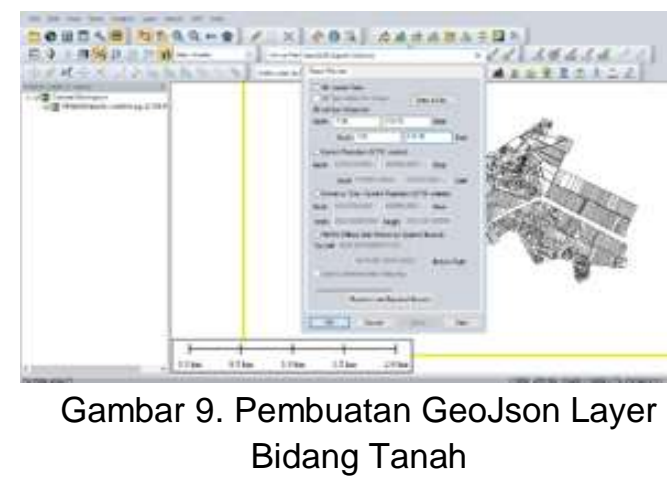




\section{Penyajian Basis Data Penggunaan Tanah Berbasis Bidang Tanah Desa Blimbing}

Dalam rangka meningkatkan kualitas pelayanan pertanahan maka penyajian data maupun informasi terkait bidang tanah perlu disajikan dalam sebuah sistem yang terintegrasi, interaktif dan mudah diakses. Untuk mencapai tujuan tersebut maka beberapa tahapan dalam penyusunan sistem informasi bidang tanah disajikan sebagaimana proses berikut.

1) Model UML Sistem Informasi Penggunaan Tanah Berbasis Bidang Tanah

Klasifikasi pengguna sistem informasi dalam kajian ini dibedakan menjadi 2 (dua) yaitu Admin dan User, terhadap dua pengguna tersebut tentunya perlu ditetapkan terkait hak akses dalam penggunaan sitem informasi. Pembagian hak pengguna oleh admin dan oleh user dalam kajian ini diklasifikasikan sebagai berikut:

[1] Admin

Admin dengan hak akses administrator memiliki kewenangan penuh terhadap aplikasi untuk melakukan edit data, hapus data, tambah data, lihat data, dan eksport GeoJson sebagai layer bidang tanah. [2] User

User dalam aplikasi ini hanya mempunyai hak ases untuk menambahkan data dan melihat data.

2) User Interface (UI) Sistem Informasi User interface merupakan tahapan perancangan sistem yang menghubungkan antara pengguna dengan basis data. $\mathrm{Di}$ dalam pembuatan basis data ini, untuk menjaga tingkat keamanan data diperlukan pembuatan Password dan halaman login. Beberapa hal yang perlu diperhatikan dalam menyusun halaman login ini diantaranya menu yang ditampilkan dibuat secara menariuk namun memberikan informasi yang jelas dan tidak membingungkan bagi pengguna. Pembangunan Sistem Informasi Penggunaan Tanah Berbasis Bidang Tanah ini dirancang menggunakan bahasa PHP dengan software Sublime Text 3.

3) Form Login dan Form Registrasi Saat pertama kali mengakses Sistem Informasi Penggunaan Tanah Berbasis Bidang, tampilan pertama yang akan muncul adalah form login. Pada form ini user diminta untuk masukkan username dan password untuk masuk ke tampilan utama.

4) Tampilan Utama

Sistem Informasi Penggunaan Tanah ini hanya menggunakan satu tampilan utama. Di dalam Tampilan utama halaman Web Sistem Informasi Penggunaan Tanah terbagi menjadi 3 (tiga) bagian, yaitu Menu Utama, Kotak Penampilan Peta, Menu Pencarian, dan Menu Kotak Informasi. Pada setiap bagian dari Menu Utama, Kotak Penampilan Peta, Menu Pencarian, dan Menu Kotak Penampilan Peta dan Menu Kotak Informasi terdapat Sub-menu yang berfungsi sebagai tindakan yang dapat dilakukan oleh pengguna.

[1] Menu Utama

Pada tampilan menu utama terdapat 2 (dua) submenu, yaitu nama dari sistem informasi yang dibuat yakni "SIPeTan" sebagai singkatan dari Sistem Informasi Penggunaan 
Tanah. Sementara submenu kedua yakni User yang berguna untuk melakukan logout.

[2] Menu Pencarian

Pada menu pencaraian ini terdiri dari 3 (tiga) submenu yaitu, pencarian menggunakan NOP, NIB, dan Nama. Sistem ini dibangun dengan memberikan keleluasaan bagi user untuk melakukan pencarian sehingga dengan memasukkan salah satu dari data NOP/ NIB ataupun Nama dalam menu pencarian kemudian menekan tombol cari, maka data yang dikehendaki oleh user terkait basis data penggunaan tanah berbasis bidang dapat dimunculkan informasinya.

[3] Kotak Penampilan Peta

Kotak penampilan peta berfungsi sebagai jendela untuk menampilkan gambaran lokasi bidang tanah, dimana dalam kotak penampilan peta ini terdapat gambaran Citra lokasi, Layer bidang, dan point bidang tanah. Didalam kotak penampilan peta ini juga terdapat pilihan apakah layer bidang ingin ditampilkan atau tidak. Selain itu menu yang ada dapat memberikan pilihan dalam menampilkan informasi mengenai penggunaan tanah suatu bidang tanah.

[4] Menu Kotak Informasi

Di dalam kotak informasi terdapat beberapa kolom informasi yang berguna untuk mengedit dan menambahkan data bidang tanah, hal ini berfungsi untuk melakukan perbaikan data dan menambahkan data apabila terdapat kekeliruan ataupun terdapat data bidang tanah yang belum masuk dalam sistem informasi.

\section{Uji Coba dan Manfaat Sistem Informasi Penggunaan Tanah Berbasis Bidang Tanah}

1) Pengujian Sistem oleh user

Sistem informasi yang baik tentunya harus memenuhi persyaratan mudah diakses, informatif, komunikatif, terintegrasi, akuntable, serta memberikan kemudahan dalam membantu pekerjaan bagi user. Di dalam kajian ini untuk mewujudkan sistem informasi sebagaimana tersebut di atas, maka diperlukan proses pengujian sistem, yang dilakukan melalui pengujian sistem bagi user. Jumlah responden untuk melakukan uji sistem dalam kajian ini terdiri 4 (empat) orang yang yakni dari 2 (dua) orang merupakan PNS Kantor Pertanahan Kabupaten Sukoharjo dan 2 (dua) orang PNS Dinas Pekerjaaan Umum dan Penataan Ruang Kabupaten Sukoharjo. Pengujian dilakukan dengan menggunakan dan mencoba menjalankan menu yang ada di dalam aplikasi. Hasil pengujian sistem informasi penggunaan tanah berbasis bidang dalam kajian ini adalah seoerti terlihat pada Tabel 2.

Tabel 2. Hasil Pengujian Sistem Informasi

\begin{tabular}{clcccc}
\hline \multirow{2}{*}{ No } & \multirow{2}{*}{$\begin{array}{c}\text { Obyek } \\
\text { Penilaian }\end{array}$} & R1 & R2 & R3 & R4 \\
\cline { 2 - 6 } & Tampilan & B & C & C & B \\
2 & $\begin{array}{l}\text { Mudah } \\
\text { dioperasikan }\end{array}$ & C & B & B & B \\
Menu yang \\
3 & $\begin{array}{l}\text { mudah } \\
\text { dipahami }\end{array}$ & B & C & B & C \\
4 & $\begin{array}{l}\text { Pencarian } \\
\text { data } \\
\text { Kemudahan } \\
\text { penyajian } \\
\text { data } \\
\text { Memberi }\end{array}$ & C & C & C & B \\
\hline & B & C & C & B \\
\hline
\end{tabular}


Hasil penilaian dari 4 (empat) responden (2 orang dari BPN dan 2 orang dari Dinas PUPR) yaitu R1 (responden 1), R2 (responden 2), R3 (Responden 3), dan R4 (responden 4) berada pada rentang nilai cukup dan nilai baik, dimana nilai untuk nilai $B$ (baik) bernilai 3, C (cukup) bernilai 2, dan K (kurang) bernilai 1. Dalam pengujian sistem tidak terdapat penilaian yang menyatakan nilai $\mathrm{K}$ yang berarti kurang. Hasil evaluasi sistem informasi penggunaan tanah oleh responden disajikan pada Tabel 3.

Tabel 3. Analisis Evaluasi Sistem Informasi

\begin{tabular}{ccccccc}
\hline $\begin{array}{c}\text { Perta- } \\
\text { nyaan }\end{array}$ & $\begin{array}{c}\mathrm{R} \\
1\end{array}$ & $\mathrm{R} 2$ & $\mathrm{R} 3$ & $\mathrm{R} 4$ & $\begin{array}{c}\text { Jml } \\
\text { Nilai }\end{array}$ & $\begin{array}{c}\text { Index } \\
(\%)\end{array}$ \\
\hline 1 & 3 & 2 & 2 & 3 & 10 & $83 \%$ \\
2 & 2 & 3 & 3 & 3 & 11 & $91 \%$ \\
3 & 3 & 2 & 3 & 2 & 10 & $83 \%$ \\
4 & 2 & 2 & 2 & 3 & 9 & $75 \%$ \\
5 & 2 & 3 & 2 & 3 & 10 & $83 \%$ \\
6 & 3 & 2 & 3 & 2 & 10 & $83 \%$ \\
\hline \multicolumn{7}{c}{ Jumlah } \\
\hline \multicolumn{7}{c}{ Suata-rata } \\
\hline \multicolumn{1}{c}{ Sumber: }
\end{tabular}

Tabel 3 menunjukkan bahwa aplikasi yang dibangun dapat memberi manfaat dan cukup memberi kontribusi dengan hasil rata-rata pengolahan data sebesar $83 \%$ (baik).

\section{2) Pengujian Analisis Sistem}

Dalam kajian ini juga dilakukan pengujian terhadap sistem informasi yang di buat dengan metode (Performance, Information, Economy, Control, Eficiency and Service) PIECES. Metode PIECES merupakan metode analisis sebagai dasar untuk memperoleh pokok-pokok permasalahan yang lebih spesifik (Ragil $2010,17)$. Metode pengujian ini dapat dilihat pada Tabel 4.
Tabel 4. Tabel pengujian dengan metode PIECES

\begin{tabular}{|c|c|}
\hline $\begin{array}{c}\text { Jenis } \\
\text { Analisis }\end{array}$ & Sistem Yang Diajukan \\
\hline $\begin{array}{l}\text { Perfor- } \\
\text { mance }\end{array}$ & $\begin{array}{lr}\text { Proses pencarian data lebih } \\
\text { mudah,cepat, } & \text { sehingga } \\
\text { mempersingkat } & \text { waktu } \\
\text { pengolahan data. } & \end{array}$ \\
\hline Information & $\begin{array}{l}\text { Sistem informasi mudah } \\
\text { diperbarui, sehingga data } \\
\text { sesuai dengan keadaan saat } \\
\text { ini. }\end{array}$ \\
\hline Economic & $\begin{array}{l}\text { Mengurangi } \quad \text { kegiatan } \\
\text { pengecekan lapang, } \\
\text { mengurangi biaya transportasi } \\
\text { dan menghemat waktu. }\end{array}$ \\
\hline Control & $\begin{array}{l}\text { Sistem informasi berbasis } \\
\text { Web dan saling terkoneksi } \\
\text { antar instansi dapat } \\
\text { memudahkan dalam kontrol } \\
\text { dan pengawasan mengenai } \\
\text { penggunaan tanah. }\end{array}$ \\
\hline Eficiency & $\begin{array}{l}\text { Lebih cepat dan efisien dalam } \\
\text { pengolahan data karena } \\
\text { dalam satu sistem informasi } \\
\text { sudah memuat beberapa data } \\
\text { mengenai bidang tanah, selain } \\
\text { itu juga mudah dalam } \\
\text { pencarian data. }\end{array}$ \\
\hline
\end{tabular}

3) Manfaat Sistem Informasi

Sistem Informasi Penggunaan

Tanah Berbasis Bidang (SIPeTan) menggambarkan suatu sistem informasi yang berisi tentang informasi penggunaan tanah dari hasil pengolahan data pertanahan (data GeoKKP), PBB (nomor objek wajib pajak beserta informasi subyek pajak), dan pengecekan langsung di lapangan (ground check).

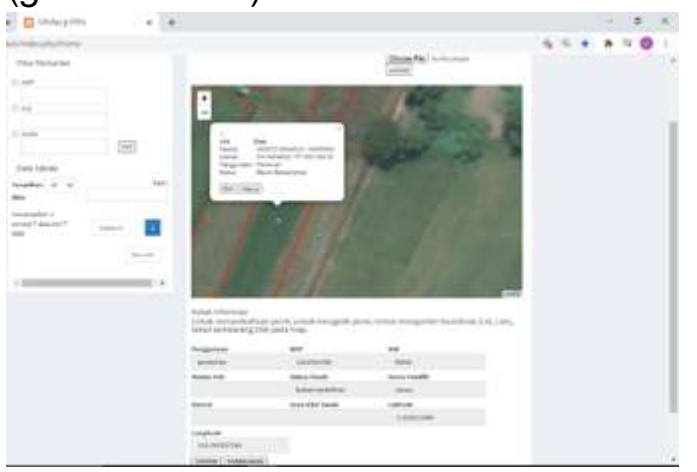

Gambar 8. Aplikasi SIPeTan 
Secara substansi pemanfaatan sistem informasi yang telah dibangun dalam kajian ini mampu memberikan beberapa informasi yang dapat digunakan oleh user untuk berbagai kepentingan, diantaranya meliputi:

1) Nomor Objek Pajak (NOP): sebagai acuan dalam pengadministrasian Pajak Bumi dan Bangunan (PBB);

2) Nomor Induk Bidang (NIB), Nomor Hak, dan Status Tanah: sebagai identifikasi bidang-bidang tanah berdasarkan data pertanahan dengan tujuan untuk membantu mewujudkan desa lengkap;

3) Nama dan alamat pemilik: sebagai informasi mengenai data diri subyek hak, data ini dapat dimanfaatkan untuk meminimalisir terjadinya tumpang tindih penguasaan/pemilikan tanah, selain itu data ini dapat pula dimanfaatakan untuk mengetahui apakah dalam suatu wilayah terdapat tanah absentee, ataupun terdapat adanya indikasi tanah terlantar.

4) Penggunaan Tanah: data ini memiliki peran penting sebagai informasi bagi instansi terkait dalam hal ini BPN maupun Pemerintah Daerah dalam menyusun Rencana Tata Ruang sesuai dengan kondisi di lapangan. Pemanfaatan data penggunaan tanah berbasis bidang juga dapat digunakan untuk mengetahui ketersediaan tanah sekaligus penguasaan tanah guna mendukung kemudahan dalam OSS (One Single Submission)

Sistem informasi 'SIPetan' yang disusun dalam kajian ini harapannya mampu menjadi sebuah aplikasi yang memudahkan berbagai pihak untuk mendapatkan informasi penggunaan tanah berbasis bidang sebagai bahan pertimbangan dalam merumuskan berbagai kebijakan. Penyusunan informasi ini juga dapat dikembangkan sebagai proses monitoring perubahan penggunaan lahan secara periodic dalam suatu wilayah. Ketersediaan data yang akurat dan mudah diakses ini harapanya mampu memberikan kemudahan dalam mendukung pembangunan serta kemajuan dalam suatu wilayah secara berkelanjutan.

\section{Penutup}

Citra Peliades sebagai salah satu citra resolusi tinggi cukup compatible untuk menyajikan informasi tutupan lahan guna menyusun peta penggunaan tanah berbasis bidang. Kemampuan penyajian obyek yang cukup detail dalam citra ini juga mampu memberikan informasi batas-batas bidang tanah pada wilayah khususnya sawah. Pemanfaatan Pleiades sebagai peta basis/dasar dalam proses overlay antara data GeoKKP dengan peta PBB juga cukup membantu dalam menyatukan data bidang-bidang tanah actual dan sebagai control dalam menyusun peta bidang tanah.

Sistem informasi penggunaan tanah berbasis bidang dirancang dan dibangun untuk memberikan kemudahan dalam proses identifikasi penggunaan tanah berbasis bidang serta informasi lain terkait obyek dan subyek bidang-bidang tanah. Manfaat dari Sistem Informasi Penggunaan Tanah Berbasis Bidang ini mampu menyajikan analisis data secara langsung dari data yang telah diinput ke dalam basis data, dan mampu mencari data pemilikan tanah berdasarkan NOP, NIB, dan Nama. Pemanfaatan lebih 
lanjut dalam sistem informasi ini dapat digunakan sebagai alat monitoring dan evaluasi perubahan penggunaan tanah serta kebijakan terkait arahan penggunaan/pemanfaatan tanah sesuai. Sistem ini juga mampu mengatasi keterbatasan SDM dalam melaksanakan survei penggunaan, pemilikan tanah serta mempermudah dalam pengelolaan dan identifikasi informasi mengenai penggunaan bidang tanah. Sistem informasi yang dibangun secara online ini juga memungkinkan proses sinkronisasi data, integrasi informasi/data antar instansi mengenai perubahan penggunaan tanah.

\section{Ucapan Terima Kasih}

Penulis mengucapkan terimakasih kepada Sekolah Tinggi Pertanahan Nasional atas terselenggaranya penelitian ini. Penulis juga berterimakasih kepada Bapak Slamet Muryono yang telah memberikan masukan terhadap perbaikan naskah penelitian.

\section{Daftar Pustaka}

Arief, R. (2011). Pemrograman web dinamis menggunakan PHP \& MySQLI, Andi, Yogyakarta.

Artika, I G. K., \& Utami, W. (2020). Percepatan pembenahan data bidang tanah kluster 4 melalui survei data pertanahan, Bhumi, Jurnal Agraria dan Pertanahan, 6 (1), 66-79.

Asyita, M., \& Taufik, M. (2013). Sistem informasi pertanahan untuk evaluasi bidang tanah (Studi kasus: Perumahan Bumi Marina Emas Kelurahan Keputih Kecamatan Sukolilo Surabaya), Jurnal Teknik Pomits, X (X),
Gifari, R. M. (2019). Analisis Harga Lahan di Kota Sintang dengan Pemanfaatan Citra Pleiades. Universitas Muhammadiyah Surakarta.

Ginanjar, P., Sudarsono, B., \& Sasmito, B. (2014). Kajian efektivitas Pemanfaatan Sistem GeoKKP untuk penerbitan sertipikat tanah di kantor pertanahan Kabupaten Kendal Provinsi Jawa Tengah, Jurnal Geodesi Undip, 3 (2), 5368.

Hapsari, E., \& Murti, S. H. (2015). Klasifikasi Berbasis Objek pada Citra Pleiades untuk Pemetaan Ketersediaan Klasifikasi Berbasis Objek pada Citra Pleiades untuk Pemetaan Ketersediaan Ruang Terbuka Hijau di Perkotaan Purwokerto 2013. Pertemuan IImiah Tahunan MAPIN XX 2015, (July), pp. 244-254.

Harsono, D. (2009). Implementasi Kebijakan Sistem Informasi Dan Manajemen Pertanahanan Nasional ( Simtanas ) Di Kantor Pertanahan Kabupaten Jepara, Tesis Pada Magister Administrasi, Universitas Diponegoro, Semarang.

Hastuti, S. D. (2020). Pengendalian pemanfaatan ruang melalui izin lokasi dalam rangka perolehan tanah yang diperlukan usaha, Jurist-Diction, 3 (3), 1099-1121.

Idrus, W. R. (2009). Land Bulletin LMPDP: Sistem SIP dan SIG Dalam Rangka Penyelenggaraan Pengelolaan Pertanahan, Edisi 12. Bappenas, Jakarta

Jayuli, A. (2017). Penegakan hukum penataan ruang dalam rangka mewujudkan pembangunan 
berkelanjutan, Richtsvinding Media Pembinaan Hukum Nasional, 6 (2), 271-289.

Korlena, Djuenaedi, A., Probosubanu, L., \& Ismail, N. (2011). Peraturan zonasi: Peran dalam pemanfaatan ruang dan pembangunan kembali di kawasan rawan bencana Kasus: Arkadelphia city, Arkansas USA, Forum Teknik, 34 ( 1).

Manalu, R. J, Sutanto, A., \& Trisakti, B. (2016). Perbandingan Metode Klasifikasi Penutup Lahan Berbasis Piksel dan Berbasis Obyek Menggunakan Data Pisar$L 2$, Jurnal Penginderaan Jauh dan Pengolahan Data Citra Digital. 13 (1), pp. 49-60.

Nurwadjedi, Rosalina, L., \& Wibowo, Y. (2019). Membangun satu peta untuk Penataan Ruang, Seminar Nasional BIG, semnas.big.go.id.

Peraturan Pemerintah Nomor 24 Tahun 2018 Tentang Pelayanan Perizinan Berusaha Terintegrasi Secara Elektronik (OSS).

Pujianto, A. K., \& Sukojo, B. M. (2016). Analisis Ketelitian Geometrik Citra Pleiades $1 \mathrm{~A}$ untuk Pembuatan Peta Dasar Lahan pertanian (Studi kasus: Kecamatan Socah, Kabupaten Bangkalan, Jurnal Teknik ITS, 5 (2).

Puspitasari, F. E. (2015). Rancang Bangun Sistem Informasi Sertipikasi Tanah Kantor Pertanahan Kabupaten Kebumen, Skripsi. Universitas Negeri Semarang.

Ragil, W. (2010). Pedoman sosialisasi prosedur operasi standar, Mitra Wacana Media, Jakarta.

Santoso, E. B., Iswi, A., \& Yanuasmara, I. (2020). Inovasi, masalah dan tantangan dalam penyusunan RDTR untuk OSS: Kasus pada penyusunan RDTR di Sendawar Timur, Kutai Barat, Provinsi Kalimantan Timur. Jurnal IImu Pemerintahan Widya Praja, 46 (1), 230-241.

Silviana, A. ( 2019). Kebijakan satu peta (One map policy) mencegah konflik di bidang administrasi pertanahan, Administrative law \& Governance Journal, 2 (2), 195205.

Sutanto. (1986). Penginderaan Jauh jilid 1, Gajah Mada University Press, Yogyakarta.

Utami, W., Wibowo, Y. A., Hadi, M. H., \& Permadi, F. B. (2021). The Impact of Mangrove Damage on Tidal Flooding in the Subdistrict of Tugu Semarang, Central Java. Journal of Degraded and Mining Lands Management, 9(1), 3093-3105. https://doi.org/10.15243/jdmlm.20 21.091.3093 